\title{
Applying the probability recognition criterion to recognise a deferred tax asset for unused 'secondary tax on companies' credits
}

ER Venter

Department of Accounting University of Pretoria
M Stiglingh

Department of Taxation University of Pretoria

\begin{abstract}
According to AC 501, Accounting for 'Secondary Tax on Companies (STC)', a deferred tax asset for unused STC credits is recognised if it is probable that an entity will declare dividends against which unused STC credits can be used. This study examined the dividend declaration profile of companies recognising a deferred tax asset for unused STC credits to satisfy AC 501. In a literature review, the term 'probable' was analysed, showing that future dividend declarations are only regarded as 'probable' if their likelihood is $64 \%$ to $79 \%$. A survey revealed that $45 \%$ of the surveyed companies with unused STC credits recognised a deferred tax asset for unused STC credits in their 2004 financial statements, and therefore believed they had satisfied the probability recognition criterion in $A C 501$. The survey also showed that companies that recognised a deferred tax asset have a dividend policy shareholders are familiar with, and most declare dividends annually. These two indicators can help assess the probability of future dividend declarations.
\end{abstract}

Key words

AC 501

IASB Framework

IAS 12

IFRS

Probable

Secondary Tax on Companies

\section{Background}

\subsection{Introduction}

Old Mutual (1993:3) described the introduction of Secondary Tax on Companies (“STC”) as one of the most interesting developments of the 1993 budget. STC was designed to encourage growth in new and fast-growing companies without prejudicing the fiscus to any great extent. The announcement of a dual tax system in the 1993 Budget for companies and close corporations in South Africa resulted in a reduction of the corporate tax rate and 
introduced STC at a rate of $15 \%$ on the net dividends declared by a company on or after 17 March 1993 (Business Day 1993:2). The STC rate was later reduced to 12.5\% from 13 March 1996 (Department of Finance 1996:5.6).

According to the Income Tax Act, Act 58 of 1962 (South Africa 1962) ${ }^{1}$, the amount of STC payable is based on the 'net amount' as defined in section $64 \mathrm{~B}(2)$ of the Act. The net amount is the amount by which the amount of dividends declared exceeds the sum of certain dividends that accrued to the company during the dividend cycle (section $64 \mathrm{~B}(3)$ of the Act). Where the sum of the dividends accrued exceeds the dividends declared, the excess (generally referred to as 'unused STC credits') must be carried forward and must be deemed to be a dividend which accrued to the company during the next dividend cycle of the company (section 64B(3)(a) of the Act).

When STC was introduced, a need arose for guidance on the accounting treatment that was to be used to deal with STC. The South African Institute of Chartered Accountants (SAICA) issued AC 501, Accounting for 'Secondary Tax on Companies (STC)'. This Interpretation became effective for annual periods beginning on or after 1 January 2004. It regulates the accounting treatment of STC and, more specifically, of unused STC credits.

AC 501 (SAICA 2003:§14) states the following:

To the extent that it is probable that the entity with the STC credit will declare dividends of its own against which unused STC credits can be utilised, a deferred tax asset should be recognised for such STC credits.'

The recognition of a deferred tax asset for unused STC credits therefore depends on whether future dividend declarations are probable. This requirement of $A C 501$ is based on an interpretation of the requirements of the international standard on income taxes contained in the International Financial Reporting Standards (IFRSs) (SAICA 2003:\$21). Paragraph 34 of IAS 12, Income Taxes, issued by the International Accounting Standards Board (IASB), determines that a deferred tax asset should be recognised for the carryforward of unused tax losses and unused tax credits to the extent that it is probable that future taxable profit will be available against which the unused tax losses and unused tax credits can be used (IASB 2000).

Hence, the question that needs to be answered is whether it is possible to determine, prior to a dividend declaration, whether future dividend declarations are probable. Various factors influence dividend declarations. These include the requirements of section 90 of the Companies Act, Act 61 of 1973 (South Africa 1973), common law requirements, investment and financing decisions, the information contents of dividends, the nature of an entity's shareholders and the availability of cash (CIMA 1999:269,271; Correia, Flynn, Uliana \& Wormald 2000:585,591). The complex combination of these factors and the amount of subjective judgement involved in assessing the probability of a dividend declaration prior to the declaration of any dividends suggest that there is some uncertainty as to whether one can determine clearly the probability of future dividend declarations prior to the declaration itself.

\subsection{Objective of the study}

The objective of the study was to obtain insight into the dividend declaration profile of companies that have recognised a deferred tax asset for unused STC credits, in other words,

1 Referred to as 'the Act' in the rest of this article. 
companies that believe that they have satisfied the probability recognition criterion of $A C$ 501. This study might therefore assist companies in identifying possible factors that need to be considered in assessing the probability of future dividend declarations.

\subsection{Research design}

A literature review was done, followed by a survey. The meaning of the term 'probable' was analysed in the literature review (see Section 2 of this article, below). The survey (see Section 3 of this article, below) consisted of a self-administered questionnaire which was sent to the financial directors of the top 200 companies listed on the JSE Limited (JSE), based on market capitalisation. The questionnaire contained several questions regarding the probability of future dividend declarations; and the findings thereof are presented in Section 3 of this article. Finally, the conclusions of the study are presented in Section 4.

\section{Literature review}

\subsection{Introduction}

The IFRSs contain a number of expressions indicative of various degrees of uncertainty about which some differences in interpretation can arise, because the IFRSs fail to define these words or expressions. Such terms are generally referred to as 'verbal uncertainty expressions'. The term 'probable' is one of these.

The Concise Oxford Dictionary of Current English (Sykes 1976:883) defines something that is 'probable' as something 'that may be expected to happen or prove true, likely'. The Framework for the Preparation and Presentation of Financial Statements of the IASB (IASB Framework) explains the meaning of the word 'probable' in the recognition criteria as follows (IASB 1989:§85):

The concept of probability is used in the recognition criteria to refer to the degree of uncertainty that the future economic benefits associated with the item will flow to or from the enterprise. The concept is in keeping with the uncertainty that characterises the environment in which an enterprise operates. Assessments of the degree of uncertainty attaching to the flow of future economic benefits are made on the basis of the evidence available when the financial statements are prepared.

In both the dictionary definition and the IASB Framework, the emphasis is therefore on the degree of uncertainty attached to the possibility that future economic benefits will flow to or from the entity.

While some guidance is given in the IASB Framework on the meaning of the word 'probable', the exact interpretation thereof is left to those who prepare financial statements and their auditors (Doupnik \& Richter 2003:15). Moreover, the IASB does not assign numerical values to verbal uncertainty expressions in IFRSs, and one might consider the approach followed by the IASB to be in line with the general notion that IFRSs are considered to be more principle-oriented, as opposed to rules-oriented (DiPiazza \& Eccles, 2002:40). In one sense, this is unfortunate: the literature has on numerous occasions shown that there is considerable disagreement as to the appropriate numbers (percentages) that represent verbal uncertainty in respect of expressions left undefined in the IFRSs (Theil 2002:178). It is also true that communication that uses qualitative expressions for frequencies risks being misinterpreted and misunderstood (Mosteller \& Youtz 1990:2). 
Because expressions of uncertainty that are undefined in IFRSs are interpreted differently by those who prepare financial statements, the lack of certainty could compromise the comparability of financial statements. Such comparability is said to be one of the qualitative characteristics of financial statements (Doupnik \& Richter 2003:16; IASB 1989:§39). This implies that the possibility of different interpretations may result in a loss of the interpretative usefulness of financial statements (Simon 2002:602). Thus, a lack of precise guidelines might create inconsistencies in the application of standards across entities (Shortridge \& Myring 2006:1). On the other hand, rules-based ('bright line') accounting standards may also not be desirable, as they lead to arbitrary accounting criteria which allow companies to structure transactions to circumvent unfavourable reporting (Shortridge \& Myring 2006:1). It therefore appears as though neither principles-based standards nor 'bright line' standards are ideal. Hence, the accounting profession is attempting to find a balance between the two.

As there is no 'bright line' definition of the term 'probable', it is necessary to determine the quantitative meaning of this term for the purposes of paragraph 14 of $A C 501$. In an attempt to assign a quantitative meaning to the term 'probable', research in the fields of both Psychology and Accounting was considered in this study. Although the studies cited below looked at a variety of verbal uncertainty expressions, the discussion here focuses only on their findings with regard to the term 'probable'.

\subsection{Psychological research}

A vast amount of research has been conducted in Psychology on verbal and numerical uncertainty expressions. A study conducted by Mosteller and Youtz (1990:4) showed that, based on the results of 20 previous studies that they had examined, the term 'probable' obtained a weighted average of 69\%. In his study, Theil (2002) summarises the findings of ten previous studies on the analysis of probability expressions. The term 'probable' was only analysed in five of these studies. Table 1, derived from Theil's (2002) study, sets out the findings of these studies regarding the term 'probable'.

Table 1 Mean ratings for the expression 'probable'

\begin{tabular}{|l|c|}
\hline Study & Mean rating \\
\hline Lichtenstein \& Newman (1967) & 71 \\
Clarke, Ruffin, Hill \& Beaman (1992) & 67 \\
Kong, Barnett, Mosteller \& Youtz (1999) & 64 \\
Laswad \& Mak (1997) & 65 \\
Tavana, Kennedy \& Mohebbi (1997) & 76 \\
\hline
\end{tabular}

Source: Adapted from Theil (2002:181)

Theil's (2002) study indicates that the term 'probable' obtained an average rating of 69\% in the five studies investigated, which is line with the findings of Mosteller and Youtz (1990).

Although the term 'probable' still contains subjective judgement, it is clear that the psychological studies agree on a range of certainty between $64 \%$ and $76 \%$, with an average of $69 \%$.

\subsection{Accounting research}

IAS 37, Provisions, Contingent Liabilities and Contingent Assets (IASB 2004:§23) regards an outflow of resources or events as 'probable' if the event is more likely than not to occur 
(in other words, the probability or likelihood that the event will occur is greater than the probability that it will not). KPMG (2005:9) is of the opinion that the interpretation of the term 'probable' in IAS 37 may be used as the definition of 'probable' for the purposes of IFRSs. Ernst \& Young (2005:1395) holds that the interpretation of 'probable' in the circumstances described in IAS 37 implies a probability threshold greater than $50 \%$. This threshold greater than $50 \%$ is, however, based on an opinion; and one would therefore need to consider previous Accounting research in this area to determine whether this threshold is acceptable.

Simon (2002) investigated how the financial directors of large listed companies in the United Kingdom (UK) and UK auditors interpret various probability expressions. He found that UK financial directors assigned a mean value of $72 \%$ to the term 'probable', while UK auditors assigned a mean value of 73\% to the term (Simon 2002:612,615). Simon compared these results to those of previous accounting-based studies, as summarised in Table 2 (below).

Table 2 Mean ratings for the expression 'probable'

\begin{tabular}{|l|c|}
\hline Study & Mean ratings \\
\hline Davidson (1991) & 73 \\
Houghton \& Walawski (1992) & 65 \\
Reimers (1992) & 78 \\
Amer, Hackenbrack \& Nelson (1994) & 79 \\
\hline
\end{tabular}

Source: Adapted from Simon (2002:615)

Table 2 indicates that significantly different ratings have been assigned to the term 'probable' in previous accounting-based studies - the ratings range between $65 \%$ and $79 \%$.

In a study conducted by Doupnik and Richter (2003), United States Certified Public Accountants were asked to assign a numerical value to the term 'probable' as contained in IFRSs. A mean value of $71 \%$ was obtained in that study.

It is therefore clear from the Accounting literature that there are significant differences in people's interpretations of the term 'probable'. Some believe that the threshold is as low as $51 \%$ (as a result of the wording of IAS 37), while most of the studies that have been conducted suggest a mean value between $71 \%$ and $79 \%$. The lowest mean value reported in Accounting-based studies was $65 \%$.

\subsection{Findings of the literature review}

The literature review reveals that there are definite differences in interpretations of the term 'probable', based on studies from the fields of Psychology and Accounting. One might argue that the contexts in which verbal uncertainty expressions are used might influence the numerical probability respondents would assign to these terms, but Simon (2002:604) suggests that there is considerable evidence that context is not a fundamental factor in the analysis of verbal uncertainty expressions. Several other reasons have also been considered for the differences in the interpretation of verbal uncertainty expressions. These include the vague meaning of the expressions, the fact that the meaning of such an expression is not constant across individuals and the influence of culture on the cognitive process involved in the assessment of probabilities (Doupnik \& Richter 2003:16). Taking into account such factors, it appears that the numerical value assigned to the term 'probable' ranges between $64 \%$ and $76 \%$, according to Psychology studies, and between $65 \%$ and $79 \%$, according to

Meditari Accountancy Research Vol. 14 No. 22006 : 83-95 
The probability recognition criterion for unused STC credits

Accounting studies. Based on the results of the various studies mentioned here, it appears that a probability threshold of $51 \%$ may be too low.

\section{The survey}

\subsection{Background to the questionnaire}

The survey consisted of a questionnaire sent to the top 200 JSE-listed companies. A list of the top 200 JSE-listed companies (based on their market capitalisation on 11 June 2004) was obtained from the Bureau of Financial Analysis at the University of Pretoria. A list of all the companies listed on the JSE, as well as the name and contact details of their financial director or chief financial officer, was obtained from the JSE client service. Where the contact details were not available, the company concerned was contacted telephonically to obtain the relevant information. The questionnaires were distributed via e-mail. Where an e-mail address was not available, the questionnaire was sent by fax.

The questionnaire contained a number of questions designed to provide insight into the dividend declaration profile of companies that have recognised a deferred tax asset for unused STC credits, in other words, companies that believe that they have satisfied the probability recognition criterion set out in AC 501 .

Questions were posed on the following areas:

the profile of the respondent and the company;

the existence and recognition of unused STC credits; and

the dividend policy of the company.

\subsection{Response rate}

The responses were divided into five categories.

$\square$ Category 1 represents the companies that completed the questionnaire (the 'respondents').

$\square$ Category 2 represents companies that replied informally that the company does not have any unused STC credits.

$\square$ Category 3 represents companies that replied informally that they are 'property loan stock companies'. In terms of section 64B(5)(b) of the Act, any dividend that is declared by these companies, as contemplated in section 11(s) of the Act, and that may be allowed as a deduction in the determination of taxable income of such a company is exempt from STC.

$\square$ Category 4 represents companies that replied informally that they are 'gold mining companies'. In terms of section 64B(12) of the Act, any company which after 17 March 1993 was engaged in mining for gold was permitted, by notice in writing furnished to the Commissioner no later than 31 August 1993, to elect to be exempt from the payment of STC.

$\square$ Category 5 represents companies that have delisted since 11 June 2004 .

Table 3 indicates the response rate. 


\section{Table 3 Response rate}

\begin{tabular}{|l|c|c|}
\hline & $\mathbf{n}$ & $\%$ \\
\hline Category 1 & 80 & $40 \%$ \\
Category 2 & 3 & $1.5 \%$ \\
Category 3 & 4 & $2.0 \%$ \\
Category 4 & 1 & $0.5 \%$ \\
Category 5 & 4 & $2.0 \%$ \\
\cline { 2 - 3 } Responses received & 92 & $46 \%$ \\
No response received & 108 & $54 \%$ \\
\cline { 2 - 3 } Total & 200 & $100 \%$ \\
\hline
\end{tabular}

The results that are indicated below for the profiles of the respondents and companies are analysed only for the companies that completed the questionnaire fully (Category 1).

\subsection{Profiles of the respondents and the companies}

The profiles of the respondents in Category $1(n=80)$ are the following:

$\square$ Of the questionnaires, 30\% were completed by the financial director of the company, $19 \%$ by the chief financial officer, $34 \%$ by a representative from the taxation department of the company and $17 \%$ by another representative of the company (for example, a financial manager or group financial controller).

$\square$ Of the respondents, $41 \%$ had less than five years experience, 31\% between five and ten years experience and $28 \%$ more than ten years experience.

$\square$ Respondents in general believed that they have sufficient knowledge of STC - 46\% believed that their knowledge was 'good', while 25\% believed that it was 'very good'.

$\square$ Of the respondents, 34\% believed that their knowledge of AC 501 was 'average', while $44 \%$ believed that it was 'good'.

$\square$ The highest percentage of responses (25\%) was obtained from companies that are listed in the financial sector of the JSE, while other sectors with high response rates included resources $(16 \%)$, cyclical services $(14 \%)$, non-cyclical consumer goods $(12 \%)$, cyclical consumer goods (10\%) and general industrials (10\%).

\subsection{Questions relating to the existence and recognition of unused STC credits}

3.4.1 For the 2004 financial year-end, did the company have unused STC credits? Of the respondents, 50\% $(\mathrm{n}=80)$ indicated that they had unused STC credits for the 2004 financial year-end, while the remaining $50 \%$ indicated the opposite. The results of the empirical study proved that unused STC credits do exist, and this supports the contention that there was a need to conduct this study.

3.4.2 If the company will be recognising a deferred tax asset for unused STC credits for the 2004 financial year-end, will the deferred tax asset be recognised for all unused STC credits at balance sheet date or only a portion of the unused STC credits? 


\section{Table 4 Results for Question 3.4.2}

\begin{tabular}{|l|c|c|}
\hline & Frequency & $\begin{array}{c}\text { \% } \\
\text { (n= } \mathbf{4 0})\end{array}$ \\
\hline A deferred tax asset will be recognised for all unused STC credits & 18 & 45 \\
A deferred tax asset will be recognised for a portion of the unused STC & & \\
credits & 1 & 2.5 \\
Asset not recognised, as it is immaterial & 1 & 2.5 \\
Asset not recognised, as AC 501 has not been early adopted & 18 & 45 \\
Uncertain, as the question was not answered & 2 & 5 \\
\hline Total & $\mathbf{4 0}$ & $\mathbf{1 0 0}$ \\
\hline
\end{tabular}

As AC 501 is effective for annual periods beginning on or after 1 January 2004, companies with a December 2004 year-end had to comply with AC 501, while companies with an earlier year-end could elect to adopt AC 501 early. Of the companies that recognised a deferred tax asset for unused STC credits for the 2004 year-end $(\mathrm{n}=19), 18$ companies recognised a deferred tax asset for all unused STC credits, while one company recognised a deferred tax asset for a portion of its unused STC credits. Of particular importance for the remainder of this study are the characteristics of these 19 companies, as they believe that they have satisfied the probability recognition criterion of $A C 501$.

While the other 21 companies did not recognise a deferred tax asset for unused STC credits for the 2004 year-end, they will be required to do so in future when AC 501 is eventually adopted and if future dividend declarations are considered to be probable. Where applicable, the results obtained from all 40 companies are provided in the further analyses below, in order to give an indication of the number of companies that might satisfy the probability recognition criterion of AC 501.

\subsubsection{If the company did have unused STC credits for the 2004 financial year-end,} what is the Rand amount of such unused STC credits (before multiplying with the STC rate of $12.5 \%)$ ?

Table 5 Results for Question 3.4.3

\begin{tabular}{|l|cc||cc|}
\hline & Frequency & $\begin{array}{c}\text { \% } \\
(\mathbf{n = 1 9 )}\end{array}$ & Frequency & $\begin{array}{c}\text { \% } \\
(\mathbf{n}=\mathbf{4 0})\end{array}$ \\
\hline Less than R1 million & 4 & 21 & 6 & 15 \\
More than R1 million, less than R10 million & 2 & 11 & 7 & 17 \\
More than R10 million, less than R50 million & 5 & 26 & 10 & 25 \\
More than R50 million, less than R100 million & 2 & 10 & 3 & 8 \\
More than R100 million, less than R1 billion & 4 & 21 & 10 & 25 \\
More than R1 billion & 2 & 11 & 3 & 8 \\
Question not answered & 0 & 0 & 1 & 2 \\
\hline Total & $\mathbf{1 9}$ & $\mathbf{1 0 0}$ & $\mathbf{4 0}$ & $\mathbf{1 0 0}$ \\
\hline
\end{tabular}

The empirical evidence indicates that the appropriateness of the recognition of a deferred tax asset for unused STC credits is an important consideration. Potentially large amounts are involved, as $8 \%(n=40)$ of these companies need to consider whether it is appropriate to recognise an asset for unused STC credits in excess of R125 million (R1 billion $\mathrm{x}$ 12.5\%). For the 2004 financial year-end, two companies actually recognised a deferred tax asset in excess of R125 million. 
3.4.4 If the company will be recognising a deferred tax asset for unused STC credits for the 2004 financial year-end, over what period does management expect the full benefit of the asset to be realised?

Table 6 Results for Question 3.4.4

\begin{tabular}{|l|cc|}
\hline & Frequency & $\begin{array}{c}\text { \% } \\
\text { (n = 19) }\end{array}$ \\
\hline One year or less & 13 & 69 \\
More than one year, but not more than 5 years & 4 & 21 \\
More than 5 years, but not more than 10 years & 1 & 5 \\
More than 10 years & 1 & 5 \\
\hline Total & $\mathbf{1 9}$ & $\mathbf{1 0 0}$ \\
\hline
\end{tabular}

Nineteen companies recognised a deferred tax asset for unused STC credits, and they therefore believe that future dividend declarations are probable. Of these companies, $69 \%$ believed that the benefit of the asset would realise within one year or less and $21 \%$ believed that it would realise after one year, but in less than five years. Even though the period over which the benefit will realise might not necessarily influence the probability of future dividend declarations, it could affect the value of the deferred tax asset. IAS 12, Income Taxes (IASB 2000:§53) specifically states that deferred tax assets may not be discounted. One might raise the question of whether this is appropriate in the case of a deferred tax asset for unused STC credits.

\subsection{Questions relating to the dividend policy of the company}

\subsubsection{Does the company have a dividend policy that shareholders are familiar} with and what is the nature of such a policy?

Table 7 Results for Question 3.5.1

\begin{tabular}{|l|cr||cc|}
\hline & Frequency & $\begin{array}{c}\text { \% } \\
(\mathbf{n}=\mathbf{1 9})\end{array}$ & Frequency & $\begin{array}{c}\text { \% } \\
(\mathbf{n}=\mathbf{4 0})\end{array}$ \\
\hline $\begin{array}{l}\text { Dividend policy } \\
\text { The policy provides for a fixed percentage of profits } \\
\text { to be distributed }\end{array}$ & 16 & 84 & 35 & 88 \\
\cline { 2 - 5 } $\begin{array}{l}\text { The policy offers shareholders a reasonable return } \\
\text { on their investment, but the percentage of profits to } \\
\text { be distributed is not stated in the policy }\end{array}$ & 8 & 50 & 13 & 37 \\
$\begin{array}{l}\text { Other (constant dividend cover, etc.) } \\
\text { Policy not to distribute dividends }\end{array}$ & 6 & 38 & 15 & 43 \\
No dividend policy & 2 & 12 & 5 & 14 \\
\hline Total & 0 & 0 & 2 & 6 \\
\cline { 2 - 5 } & 3 & 16 & 5 & 12 \\
\hline
\end{tabular}

If a company has a fixed dividend policy to distribute profits that shareholders are familiar with, it might be an indication that the probability of future dividend declarations is quite high. This is confirmed by that fact that $84 \%$ of the companies that recognised a deferred tax asset for unused STC credits have a dividend policy with which their shareholders are familiar. Three of the companies that did recognise a deferred tax asset for unused STC credits, however, do not have a policy with which their shareholders are familiar. These companies might therefore have considered other factors to determine whether future dividend declarations are probable. 
Two of the companies that do have a policy with which their shareholders are familiar indicated that they have a policy not to distribute dividends. All the other companies' policies varied between a policy to distribute a fixed percentage of profits, a policy to maintain a constant dividend cover or a policy to offer shareholders a reasonable return on their investment. All these policies might indicate that future dividend declarations are probable for these companies, because, as long as a company does not have a policy not to distribute dividends, shareholders have some expectation of future dividend declarations. As expected, none of the companies which recognised a deferred tax asset for unused STC credits have a policy not to distribute profits.

It appears that of the companies that applied AC 501 for the 2004 year-end, in general, most (84\%) recognised a deferred tax asset for unused STC credits if they had a distributive dividend policy with which their shareholders are familiar. One might therefore argue that this is one of the factors that entities should consider in their assessment of the probability of future dividend declarations. Based on this indicator alone, $82 \%$ (88\% minus $6 \%$ ) of all the companies with unused STC credits would need to consider recognising a deferred tax asset for unused STC credits, as 6\% have a policy not to distribute dividends.

\subsubsection{Does the company declare dividends on an annual basis?}

Table 8 Results for Question 3.5.2

\begin{tabular}{|l|rr||rr|}
\hline & Frequency & $\begin{array}{c}\text { \% } \\
(\mathbf{n = 1 9})\end{array}$ & Frequency & $\begin{array}{c}\text { \% } \\
(\mathbf{n}=\mathbf{4 0})\end{array}$ \\
\hline Always & 14 & 74 & 28 & 70 \\
Mostly & 4 & 21 & 7 & 18 \\
Sometimes & 0 & 0 & 0 & 0 \\
Very seldom & 1 & 5 & 2 & 5 \\
Never & 0 & 0 & 3 & 7 \\
\hline Total & $\mathbf{1 9}$ & $\mathbf{1 0 0}$ & $\mathbf{4 0}$ & $\mathbf{1 0 0}$ \\
\hline
\end{tabular}

Mosteller and Youtz (1990:4) state that the term 'always' scored a weighted average mean percentage of $99 \%$ in the 20 previous studies which they investigated. The American Heritage Dictionary of the English Language (2005) defines 'mostly' as 'generally, usually'. Mosteller and Youtz (1990:4) assigned a weighted mean percentage of $79 \%$ to the term 'usually'. It therefore looks as though the terms 'always' and 'mostly' would satisfy the probability recognition criterion of $A C 501$ : based on the studies discussed in the literature review, it appears that the term 'probable' has a numerical value of between $65 \%$ and $79 \%$. The term 'sometimes' is assigned a weighted average mean value of $26 \%$ by Mosteller and Youtz (1990:4). Of the companies that recognised a deferred tax asset for unused STC credits, 95\% stated that they 'always' (74\%) or 'mostly' (21\%) distribute a dividend on an annual basis.

Three companies that recognised a deferred tax asset for unused STC credits indicated that they do not have a dividend policy with which their shareholders are familiar (see Table 7). Two of these companies, however, 'always' declare dividends on an annual basis. Even though these companies do not have a dividend policy with which their shareholders are familiar, it appears to be appropriate to recognise a deferred tax asset for unused STC credits, as there is a $99 \%$ probability that they will declare dividends in future, resulting in the balance of unused STC credits being used. The other company that does not have a dividend policy with which its shareholders are familiar 'very seldom' declares dividends 
on an annual basis. This company also indicated that it expects the balance of unused STC credits to realise over a period between five and ten years (see Table 6 above). It is uncertain on which basis this company performed the probability assessment of the future declaration of dividends.

It appears that of the companies that applied AC 501 for the 2004 year-end, in general, most (95\%) recognised a deferred tax asset for unused STC credits if they 'always' or 'mostly' declare dividends on an annual basis. One might therefore argue that this is one of the factors that entities should consider in their assessment of the probability of future dividend declarations. Based on this indicator alone, $88 \%(n=40)$ of all the companies with unused STC credits would need to consider recognising a deferred tax asset for unused STC credits.

\subsection{Findings of the survey}

The survey consisted of a questionnaire which contained several questions to obtain insight into the dividend declaration profile of companies that have recognised a deferred tax asset for unused STC credits, in other words, companies that believe that they have satisfied the probability recognition criterion of $A C 501$. Responses were received from 80 companies, of which 40 companies had unused STC credits, while 19 recognised a deferred tax asset for unused STC credits for the 2004 financial year-end.

The results indicated that two factors might be important considerations in assessing the probability of future dividend declarations, namely whether the company has a distributive dividend policy with which their shareholders are familiar ('Indicator 1') and whether the company distributes dividends on an annual basis ('Indicator 2'). The findings of the survey are summarised in Table 9 below:

\section{Table 9 Summary of results}

\begin{tabular}{|l|cr||rr|}
\hline & Frequency & $\begin{array}{c}\text { \% } \\
(\mathbf{n}=\mathbf{1 9})\end{array}$ & Frequency & $\begin{array}{c}\% \\
(\mathbf{n}=\mathbf{4 0})\end{array}$ \\
\hline Companies only meeting Indicator 1 & 0 & 0 & 0 & 0 \\
Companies only meeting Indicator 2 & 2 & 11 & 2 & 5 \\
Companies meeting Indicators 1 and 2 & 16 & 84 & 33 & 83 \\
None of the above & 1 & 5 & 5 & 12 \\
\hline Total & $\mathbf{1 9}$ & $\mathbf{1 0 0}$ & $\mathbf{4 0}$ & $\mathbf{1 0 0}$ \\
\hline
\end{tabular}

It therefore appears that the existence of both Indicators 1 and 2 might be significant considerations in the assessment of the probability of future dividend declarations.

\section{Conclusion}

The objective of the study was to obtain insight into the dividend declaration profile of companies that recognise a deferred tax asset for unused STC credits, in other words companies that believe that they have satisfied the probability recognition criterion of $A C$ 501. The results of this study might assist companies in identifying possible factors that need to be considered in the probability assessment of future dividend declarations.

The literature review indicated that there are various interpretations of the term 'probable'. Some people believe that the threshold is as low as 51\%, while others believe that it is as high as $79 \%$. Studies in the fields of Psychology and Accounting suggested that 
future dividend declarations would only be considered probable if the probability assessment is within the range between $64 \%$ and $79 \%$.

Of the top 200 JSE-listed companies, 80 completed the questionnaire that formed part of the survey. Of these companies, $50 \%$ indicated that they have unused STC credits, while $48 \%$ of the companies with unused STC credits indicated that they had recognised a deferred tax asset for unused STC credits for the 2004 financial year-end. These companies therefore believe that they have satisfied the probability recognition criterion of $A C 501$. Of the companies that recognised a deferred tax asset for unused STC credits $(\mathrm{n}=19), 84 \%$ have a dividend policy with which shareholders are familiar and $74 \%$ 'always' declare dividends on an annual basis, while $21 \%$ 'usually' declare dividends on an annual basis. It therefore appears that if a company has a distributive dividend policy with which shareholders are familiar and the entity has a history of paying dividends on an annual basis, this might indicate that future dividend declarations are probable. One company which recognised a deferred tax asset for all unused STC credits did not have a dividend policy with which shareholders are familiar and it 'very seldom' declares dividends on an annual basis.

This finding again indicates the difference in the interpretation and application of verbal uncertainty expressions in IFRSs and the finding supports the contention that there potential drawbacks to principles-based accounting standards, as outlined by Shortridge and Myring (2006). A lack of precise guidelines might create inconsistencies in the application of standards across entities (Shortridge \& Myring 2006:1). While it is clear that hard and fast rules are not always desirable, broad guidance might still be required for areas of divergent practices, one of which may be verbal uncertainty expressions.

\section{Bibliography}

American Heritage Dictionary of the English Language. 2005. $4^{\text {th }}$ edition. Boston, Massachusetts: Houghton Mifflin.

Business Day. 1993. Dual company tax system to promote growth, jobs. 18 March.

CIMA. 1999. CIMA Study Text Stage 4 Paper 13 Strategic Financial Management. London: BPP.

Correia, C., Flynn, D., Uliana, E. \& Wormald, M. 2000. Financial Management. $4^{\text {th }}$ edition. Cape Town: Juta.

Department of Finance. 1996. Budget Review 13 March 1996. Pretoria: Government Printer.

DiPiazza, S.A. \& Eccles, R.G. 2002. Building public trust - the future of corporate reporting. New York: John Wiley \& Sons.

Doupnik, T.S. \& Richter, M. 2003. Interpretation of uncertainty expressions: a crossnational study. Accounting Organizations and Society, 28:15-35.

Ernst \& Young. 2005. International GAAP 2005. London: LexisNexis.

International Accounting Standards Board (IASB). 1989. Framework for the Preparation and Presentation of Financial Statements. London: IASB Publications Department. 
International Accounting Standards Board (IASB). 2000. IAS 12, Income Taxes. London: IASB Publications Department.

International Accounting Standards Board (IASB). 2004. IAS 37, Provisions, Contingent Liabilities and Contingent Assets Date. London: IASB Publications Department.

KPMG. 2005. Insights into IFRS - KPMG's practical guide to International Financial Reporting Standards. 2005/6 Edition. Bath: Thomson.

Mosteller, F. \& Youtz, C. 1990. Quantifying probabilistic expressions. Statistical Science, 5(1):2-12.

Old Mutual. 1993. Budget highlights 1993.

Shortridge, R.T. \& Myring, M. 2006. Defining principles-based accounting standards. www.nysscpa.org/printversions/cpaj/2004/804/p34.htm. Accessed 4 July 2006.

Simon, J. 2002. Interpretation of probability expressions by financial directors and auditors of UK companies. The European Accounting Review, 11(3):601-629.

South Africa. 1962. Income Tax Act, Act 58 of 1962. Pretoria: Government Printer.

South Africa. 1973. Companies Act, Act 61 of 1973. Pretoria: Government Printer.

South African Institute of Chartered Accountants (SAICA). 2003. AC 501, Accounting for 'Secondary Tax on Companies (STC)'. Johannesburg: LexisNexis.

Sykes, J.B. (ed.) 1976. The Concise Oxford Dictionary of Current English. Oxford: Oxford University Press.

Theil, M. 2002. The role of translations of verbal into numerical probability expressions in risk management: a meta-analysis. Journal of Risk Research, 5(2):177-186. 